\title{
OVARIAN DYSGERMINOMA
}

Ana Devic ${ }^{1}$, Mladenko Vasiljevic $^{2}$, Aleksandar Devic ${ }^{1}$, Marija Sorak $^{3}$

${ }^{1}$ Hospital of Gynaecology and Obstetrics, Clinical Hospital Center Zemun, Zemun-Belgrade, Serbia

${ }^{2}$ University of Belgrade, Medical of Faculty, Clinic of Gynaecology and Obstetrics "Narodni Front", Belgrade, Serbia

${ }^{3}$ University of Kragujevac, Faculty of Medical Sciences, Clinic of Gynaecology and Obstetrics, Kragujevac, Serbia

\section{DISGERMINOM JAJNIKA}

\author{
Ana Dević ${ }^{1}$, Mladenko Vasiljević ${ }^{2}$, Aleksandar Dević ${ }^{1}$, Marija Šorak ${ }^{3}$ \\ ${ }^{1}$ Bolnica za Ginekologiju i Akušerstvo, Kliničko bolnički centar Zemun, Zemun-Beograd, Srbija \\ ${ }^{2}$ Univerzitet u Beogradu, Medicinski fakultet, Ginekološko - akušerska klinika „Narodni Front“ Beograd, Srbija \\ ${ }^{3}$ Univerzitet u Kragujevcu, Fakultet medicinskih nauka,Ginekološko -akušerska klinika, Kragujevac, Srbija
}

Received / Primljen: 18.02.2015

Accepted / Prihvaćen: 16.03.2015

\begin{abstract}
Ovarian dysgerminoma $(O D)$ is one of the most common malignant tumours of the ovarian germ cells, comprising 1-2\% of all malignant ovarian tumours. It most commonly occurs between the ages of 10 and 30. The treatment is primarily surgical; however, in the advanced stages of the disease, surgical treatment is followed by chemotherapy.

We report a case of a 19-year-old female patient who was diagnosed with bilateral ovarian dysgerminoma. The patient was first operated for dysgerminoma on the left ovary and an ovariectomy was performed. A month later, she underwent surgery again because of the appearance of a residual tumour in the lodge of the removed ovary; the rest of the tumour was removed at that time. The histological finding was dysgerminoma ovarii, FIGO stage 1c. As agreed on by the consulting team, the patient returned for a follow-up ultrasound examination every three months. Nevertheless, nine months after the operation, she was diagnosed with dysgerminoma of the right ovary. Surgical treatment was performed again, and the tumour was removed. The histological finding on the second occasion was dysgerminoma ovarii, FIGO stage IIa, according to the TNM classification T2aNxMx. To preserve the reproductive capacity of the patient, the consulting team agreed to treat the patient with chemotherapy, i.e., 3 cycles of BEP [Bleomycin, Etoposide, Cisplatin (Platinum)]. Magnetic resonance imaging, ultrasound and clinical examination after the therapy were normal. The patient is monitored in regular intervals, feels good and has no signs of the disease after five years.
\end{abstract}

Keywords: dysgerminoma, malignant ovarian tumour, chemotherapy, surgical intervention

\section{SAŽETAK}

Disgerminom jajnika je jedan od najčešcih malignih tumora germinativnih ćelija jajnika. On čini 1-2\% svih malignih tumora jajnika. Najčešće se javlja između 10. i 30. godine života. Lečenje je primarno hiruško. Kod uznapredovalih stadijuma bolesti nakon hiruškog lečenja primenjuje se $i$ hemioterapija.

Prikazujemo pacijentkinju staru 19 godina koja je operisana zbog disgerminoma na oba jajnika. Pacijentkinja je prvi put operisana zbog disgerminoma na levom jajniku. Urađena je ovariektomija. Mesec dana nakon operacije zbog pojave rest tumora u loži odstranjenog jajnika urađena je ponovo operacija i odstranjen je rest tumor. HP nalaz - Dysgerminoma ovarii, stadijum FIGO 1c. Nakon toga, po odluci Konzilijuma pacijentkinja je kontrolisana ultrazvučnim pregledima na 3 meseca. Devet meseci posle ove operacije dijagnostikovan je disgerminom na desnom jajniku. Uradena je operacija i odstranjen je tumor jajnika. HP nalaz - Dysgeminoma ovarii. Stadijum bolesti FIGO IIa. Prema TNM klasifikaciji T2aNxMx. Zbog očuvanja reproduktivne sposobnosti pacijentkinje, a po odluci Konzilijuma, sprovedeno je lečenje hemioterapijom,3 ciklusa po protokolu BEP [(Bleomycin, Etoposide, Cisplatin (Platinum)]. Kontrolni pregled magnetne rezonance, ultrazvuka $i$ klinički pregled nakon sprovedene terapije bili su uredni. Pacijentkinja je redovno kontrolisana $i$ pet godina nakon operacije dobro se oseća $i$ nema znakova recidiva bolesti.

Ključne reči: disgerminom, maligni tumor jajnika, hemioterapija, hiruški zahvat 


\section{INTRODUCTION}

Ovarian dysgerminoma (OD) is one of the most common malignant tumours of ovarian germ cells. It belongs to the group of germ tumours of the ovary and arises by the malignant alteration of the primordial germ cells. In some cases, the tumour may occur on the anomalies of the genital tract, such as gonad dysplasia or testicular feminization [1]. It usually occurs in patients aged 20 to 30 years. Dysgerminomas comprise $1-2 \%$ of all malignant ovarian tumours [2] and occur bilaterally in $10-15 \%$ of all cases. In approximately $5 \%$ of patients with dysgerminomas stage Ia, microscopic metastasis can be found in the other ovary. Macroscopically, the tumours are solid with lobular structure and may reach a size of approximately $15 \mathrm{~cm}$. The most common clinical symptoms are abdominal pain and the presence of a tumour mass in the abdomen [3]. The tumours usually spread through the lymphatic system into the paraaortic lymph nodes; haematogenous spread may occur in the advanced stages of the disease. Conservative surgery is the treatment of choice for unilateral encapsulated unruptured tumours, with negative retroperitoneal lymph nodes and negative swabs from the pelvic and paracolic area in order to preserve the patient's reproductive function. In advanced stages of the tumour, radical surgical procedure is followed by chemotherapy. The five-year survival rate of the disease in stage I is $80-90 \%[4,5]$.

\section{CASE REPORT}

A 19-year-old patient, nulliparous, nulligravida, menarche at the age of 14, with regular menstrual cycles at 28 days lasting for 4-5 days was admitted to the Gynaecology and Obstetrics Clinic "Narodni Front" in Belgrade for surgery because of a residual tumour in the left ovary lodge. A month prior to this admission, the patient had a laparoscopic ovariectomy performed at another hospital due to the presence of a tumour in the left ovary, which was $9 \times 8 \mathrm{~cm}$ large and of predominantly solid lobular structure. The tumour was encapsulated, and the capsule was intact. The histological finding of that tumour was dysgerminoma ovarii. A month after the aforementioned laparoscopic surgery, the patient underwent a regular follow-up ultrasound examination when another cystic formation measuring $8 \times 6 \mathrm{~mm}$ was diagnosed in the lodge where the left ovary was previously extracted. Magnetic resonance imaging of the left ovarian lodge revealed a tumour of a lobular structure, $8 \times 6 \mathrm{~mm}$ in diameter. The uterus had normal size and structure. The right ovary was normal in size, with microcystic structure. LDH, AFP, hCG and CA125 values were within normal limits. The paraaortic and pelvic lymph nodes were not enlarged. The patient was presented to the consulting team for malignant diseases, and the team decided that it was best to perform an exploratory laparotomy and to act upon the findings. The patient was operated with salpingectomy on the left side and had a tumour formation of $8 \times 6 \mathrm{~mm}$ in diameter with finely cystic structure removed. A biopsy was performed on the right ovary, which had a microcystic structure and a normal size. The right fallopian tube was normal. A partial resection of the omentum was performed. During the operation, no pathological findings were reported on the liver, stomach, small and large intestine, omentum and parietal peritoneum. Douglas's pouch contained approximately $10 \mathrm{ml}$ of fluid. The fluid was collected for cytological analysis; swabs from the left and right subdiaphragmatic region and from the left and right paracolic region were also taken. The histological finding of the removed tumour was dysgerminoma ovarii, FIGO stage 1c. A histopathological biopsy of the right ovary and the omentum showed the tissue of ovaries and omentum without pathological changes. The cytological findings on malignant cells were negative. The patient was presented to the consulting team once again after surgery, and the team decided to have her followed up every three months, including conducting magnetic resonance imaging of the abdomen and pelvis. The follow-up results after 3 months were normal. The patient was regularly monitored by ultrasound every 3 months. Nine months after surgery, however, a followup ultrasound scan revealed a tumour in the upper pole of the right ovary, predominantly of a solid material with dimensions of $3 \times 3 \mathrm{~cm}$, with a unilocular cystic formation measuring $3 \times 4 \mathrm{~cm}$ with transonic media. $\mathrm{LDH}$ values were slightly increased, while AFP, HCG and CA-125 values remained within normal limits. Magnetic resonance imaging revealed a tumour formation in the upper pole of the right ovary with a diameter $3 \times 3 \mathrm{~cm}$, multilocular, predominantly cystic structure with some solid tissue and thin partitions, as well as another unilocular cystic formation $3 \times 4 \mathrm{~cm}$ that probably corresponded to follicular cysts. The patient's karyotype was normal, 46XX. Suspecting another dysgerminoma, we decided to perform the surgery once again. The patient underwent a laparotomy with the resection of ovarian tumours in total, a punction of the cyst and a suture of the ovary. The tumour was encapsulated. The removed tumour was sent for histological analysis, and the content of the cyst was sent for cytological analysis. A peritoneal washing was collected for cytological analysis. A partial resection of the omentum was performed. No macroscopically visible secondary deposits were visible on the liver, stomach, small and large intestine, urinary bladder, omentum or parietal peritoneum. Once again, the histological finding was dysgerminoma ovarii (Figures 1 and 2).

However, the tumour was focally infiltrating the ovarian capsule. A lymphatic and vascular infiltration was not found. The disease was at FIGO IIa stage. According to the TNM classification, it was T2aNxMx. The cytological finding of the cyst and of the peritoneal washing for malignant cells was negative. The consulting team decided to carry out the adjuvant chemotherapy treatment in order to preserve the reproductive capacity of the patient. The patient received 3 cycles of chemotherapy with BEP [(Bleomycin, Etoposide, Cisplatin (Platinum)], according 


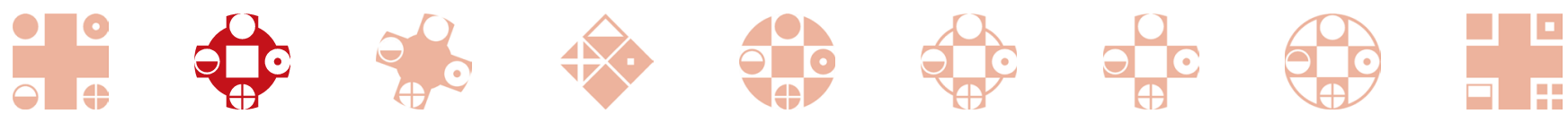

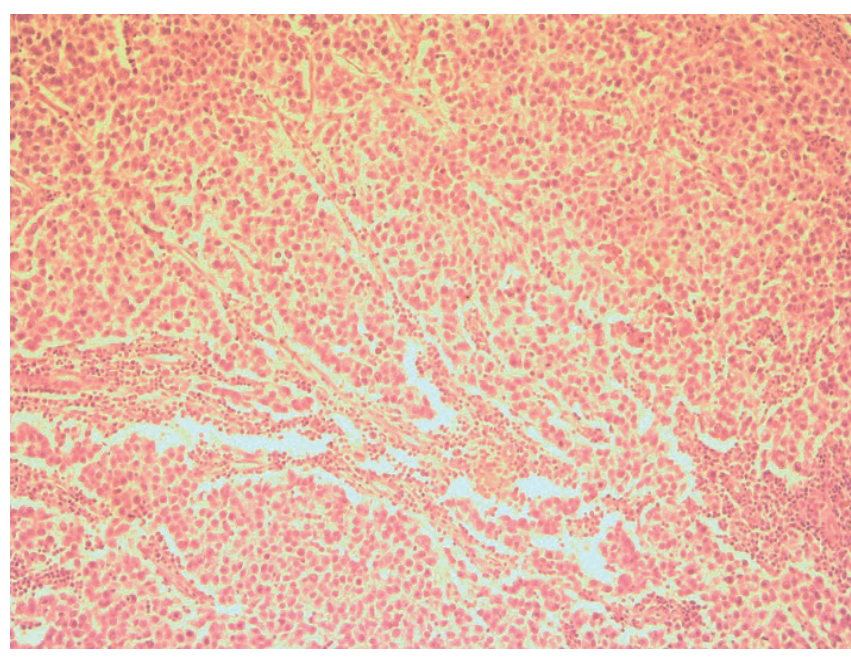

Figure 1. Dysgerminoma, 10x, haematoxylin and eosin stain

to protocol. Afterwards, she underwent a check-up magnetic resonance imaging, ultrasound and clinical examination. All findings were normal. The patient was presented to the consulting team once again, and the team decided to have her monitored every three months with magnetic resonance imaging of the pelvis and abdomen. The first follow-up imaging was uneventful, and the team decided to monitor the patient every 3 months. During the following five-year period, the patient was regularly monitored by ultrasound examination, and once a year she had magnetic resonance imaging of the abdomen and pelvis. Five years after surgery, the patient was feeling well and there was no evidence of the disease.

\section{DISCUSSION}

Dysgerminoma is the most common type of malignant germ cell tumours, comprising 1-2\% of all malignant ovarian tumours. In most cases, it occurs in women between the ages of 20 and 30 [2]. Our patient was 19 years old. In approximately $5 \%$ of cases, dysgerminoma may even occur before puberty. Dysgerminoma cells originate from the primordial sexually undifferentiated embryonic gonads. This disease may be associated with pregnancy in $17 \%$ of cases; if that is the case, the tumour can be removed, and the pregnancy can be preserved[6,7]. In approximately $2 \%$ of non-pregnant women, a pregnancy test can be positive due to the creation of hCG in the isolated syncytiotrophoblast cells. The tumour most often occurs unilaterally, which makes up approximately $80-85 \%$ of all cases. However, it occurs bilaterally in $10-15 \%$ of cases, as was the case in our patient. Dysgerminomas tend to spread by the perirectal lymphatic system to lymph nodes near the aorta [8]. It can disseminate haematogenously to the lungs, liver and bones at advanced stages of the disease. The largest part of the dysgerminoma is associated with elevated levels of serum lactate dehydrogenase $(\mathrm{LDH})$, which is sometimes

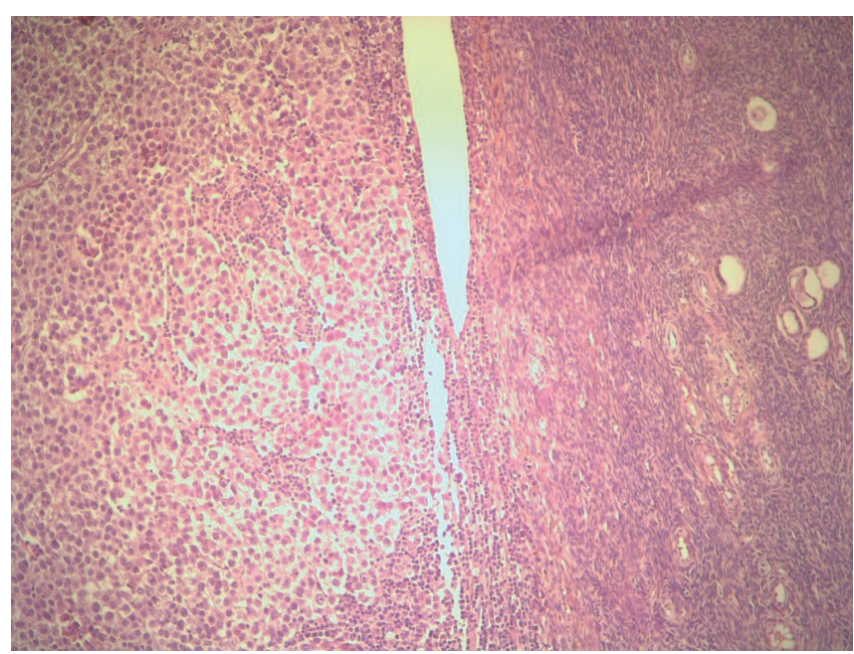

Figure 2. Dysgerminoma with ovarian tissue, 10x, haematoxylin and eosin stain

used as a tumour marker in monitoring the progression of the disease [9]. In our patient, the values of the tumour markers AFP, HCG and CA-125 were within normal limits, while LDH values were slightly increased. The main clinical feature of this tumour is its rapid growth. Symptoms usually persist from one month to six months before the tumour is diagnosed. The first symptoms are abdominal pain and vaginal bleeding, followed by abdominal distension and the presence of a mass in the abdomen[10]. Abdominal effusion and rupture of the tumour occur in $25 \%$ of cases. It is usually spread through the lymphatic paraaortalne in the lymph nodes, and haematogenous spread takes place in the advanced stages of the disease [8]. In our patient, there were no pathological findings on the liver, stomach, small and large intestine, omentum or parietal peritoneum. Douglas's pouch contained approximately $10 \mathrm{ml}$ of a free fluid. The cytological finding of this fluid and the swabs taken from the left and right subdiaphragmatic region and from the left and right paracolic region were negative. Dysgerminoma is composed of aggregates and large islands of uniform cells surrounded by varying amounts of connective tissue containing a small number of lymphocytes. The cells are round or oval with eosinophilic or light cytoplasm. The nucleus is circular with clear boundaries, finely granular chromatin and one or two nucleoli [10].

Considering the fact that $85 \%$ of women with ovarian dysgerminoma are younger than 30 years old, a conservative surgical treatment is highly recommended in order to preserve fertility. Conservative surgery is the treatment of choice for unilateral encapsulated unruptured tumours in stage Ia, with negative retroperitoneal lymph nodes and negative swabs from the pelvic and paracolic area and without dysgenetic gonads, in order to preserve reproductive function[3]. In more advanced stages of the disease, such as Ib and above, a radical surgical approach is advised. This includes hysterectomy with bilateral salpingooophorectomy, lymphadenectomy and omentectomy[4]. 
Commonly, in women with advanced-stage disease who insist on having children, a conservative surgical treatment may be applied with a certain risk. Our case was specific to the development of dysgerminoma on the right ovary following the ovariectomy of the left ovary due to the same disease. The second dysgerminoma was of stage IIa, according to FIGO classification. Despite the fact that it was diagnosed at an advanced stage, this patient underwent a conservative surgical procedure of the right ovary in order to remove the tumour only and to preserve childbearing capacity at the same time. Chemotherapy consisting of 3 cycles of BEP was applied after the surgical treatment. Dysgerminomas are sensitive to radiation; adjuvant chemotherapy is highly recommended whenever possible to preserve fertility. The so-called BEP protocol [(Bleomycin, Etoposide, Cisplatinum (Platinum)] is considered a gold standard and is widely accepted around the world[11,12]. The number of chemotherapy cycles is limited to 6 . A concurrent chemotherapy and radiation therapy are reserved for women with stage III disease. The five-year survival rate for stage I disease is $90 \%$ and approximately $74 \%$ for stage III disease[5,13].

According to the recommendations of the European Society for Medical Oncology, the clinical follow-up of patients with ovarian tumours is performed every 3 months during the first 2 years, every 4 months in the third year, and every 6 months in years 4 and 5[14]. Our patient was monitored regularly for five years after surgery and showed no evidence of the development of the disease.

\section{REFERENCES}

1. Yoon S, Park HG, Kuk JY, Oak SA, Park JH. A case of ovarian dysgerminoma with gonadal dysgenesis in 29 -year-old woman with 46,XX karyotype. Korean J Obstet Gynecol. 2012;55(10):772-6.

2. Smith HO, Berwick M, Verschraegen CF, Wiggins C, Lansing L, Muller CY, et al. Incidence and survival rates for female malignant germ cell tumors. Obstet Gynecol. 2006;107(5):1075-85.

3. Tangjitgamsol S, Hanprasertpong J, Manusirvithaya S, Wootipoom V, Thavaramara T, Buhachat R. Malignant ovarian germ cell tumors: clinic-pathological presenta- tion and survival outcomes. ActaObstetGynecol Scand. 2010;89(2):182-9.

4. Vicus D, Beiner M, Klachook S, Le L, Laframboise S, Mackay H. Purge dysgerminoma of the ovary 35 years on: A single institutional experiences. GynecolOncol. 2010:117(1):23-6.

5. Biswajit D, Patil CN, Sagar TG. Clinical presentation and outcome of pediatric ovarian germ cell tumor: A study of 40 petients. J Pediatric Hematol Oncol.2010;32(2):e54-e56.

6. Boran N, Tulunay G, Callskan E, Kose MF, Haberal A. Pregnancy outcomes and menstrual function after fertility sparing surgery for pure ovarian dysgerminoma. Arch Gynecol Obstet. 2005;271:104-8.

7. Akhtar K, Shamshad Ahmad S, Kumar A, Afshan N. Dysgerminoma with pregnancy and viable baby: a case report. Oman Med J. 2011;26(3):198-200.

8. Kumar S, Shah JP, Bryant CS, Imudia AN, Cote ML, AliFehmi R, et al. "The prevalence and prognostic impact of lymph node metastasis in malignant germ cell tumors of the ovary," GynecolOncol. 2008; 110(2): 125-32.

9. Radhakrishhnan S, Haq S, Lofts F, Young MPA, Barton DRJ. Ovarian dysgerminoma presenting with hypercalcaemia. BJOG. 2001;108(12):1302-4.

10. Lee IH, Choi CH, Hong DG, Song JY, Kim YJ, Kim KT.et al. Clinicopathologic characteristics of granulosa cell tumors of the ovary: a multicenter retrospective study. J GynecolOncol. 2011;22:188-95.

11. Pautier P, Gutierrez-Bonnaire M, Rey A, Sillet-Bach I, Chevrean C, Kerbrat P, et al. Combination of bleomycin, etoposide, and cisplatin for the treatment of advanced ovarian granulosa cell tumors. Int J Gynecol Cancer. 2008;18:446-52.

12. Talukadar S, Kumar S, Bhatla N, Mathur S, Thulkar $S$, Kumar L. Neo-adjuvant chemotherapy in the treatment of advanced malignant germ cell tumors of ovary. Gynecol Oncol.2014;132:28.

13. Zanetta G, Bonazzi C, Cantu M, Binidagger S, Locatelli A, Bratina G, et al. Survival and reproductive function after treatment of malignant germ cell ovarian tumors. J ClinOncol. 2001;19(4):1015-20.

14. Colombo N, Peiretti M, Garbi A, Garinelli S, Marini C, Sessa C. Non-epithelial ovarian cancer: ESMO clinical practice guidelines. Ann Oncol. 2012;23(7):20-6. 